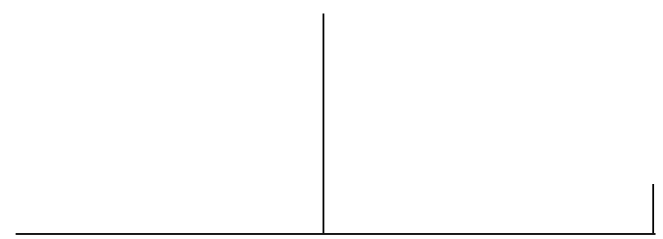

Rev. Latinoam. Psicopat. Fund., São Paulo, v. 15, n. 3, p. 649-656, setembro 2012 (Suplemento)

\title{
Anorexia: a Failure in the Work of Melancholia
}

\author{
Ana Paula Gonzaga
}

The self-reproach against their own bodies seen in patients with eating disorders has led us to posit the existence of failures in the work of melancholia. Defined by Freud in 1915, this process of melancholia is aimed at repairing a loss felt as unbearable by the ego and that triggers off a violent struggle with ambivalent feelings toward the lost object. The resulting hatred is aimed at the shadow of the object that falls on the ego. Especially in anorexia nervosa, there seems to be a regressive movement that goes beyond this.

Key words: Eating disorders, adolescence, melancholy, narcissism 
In his article Mourning and Melancholia [2011(1915)], Freud aims at discussing the mourning process - "a reaction to the loss of a loved person or a loved abstraction which has taken the place of one, such as one's country, liberty, an ideal and so on" (p. 47) - as a deinvesting work of psychism on the lost object. He thinks this process is necessary and normal, particularly through the removal of the libido falling on the no longer present object, thus leaving it free for new investments. The character of reality is, therefore, unquestionable, as well as the involvement of pre-conscious/unconscious processes.

Nonetheless, in some cases the process does not work like this; in some cases, besides disheartenment, a cessation of interest in the outside world, loss of the capacity to love, and inhibition of all capacity, there is also an impressive "lowering of the self-regarding feeling that finds utterance in self-reproaches and self-revilings" (op. cit., p. 47). Freud calls these "melancholic processes", in which he emphasizes the distinction concerning alteration of self-regarding, and also the character of loss which does not necessarily fall upon the death of a loved one, but upon its ideal nature, something lost as the object of love. He associates a ghostly and unconscious character to melancholia. And he also points out - as he did in the case of mourning, in which the character of work (psychic elaboration) is clear - the same attribute in melancholia. It is through this quality of work that melancholia allows the search for the inner reparation of a loss of the ego.

Thus Freud teaches us that if we learn how to patiently hear the multiple self-reproaches of the melancholic patient, we shall understand that his insults do not concern so much his own person, but someone he loves, loved or should love. "Thus we have the key to the clinical picture at hand, inasmuch as we acknowledge for the self-reproaches as reproaches against an object of love, from which they turned against the ego itself" (op. cit., p. 59). 


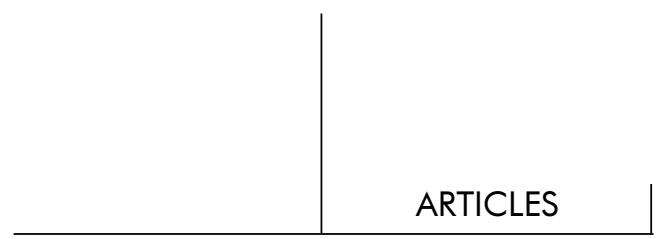

The process - the work - here emphasized by Freud as something due to melancholia is based upon the identification in which the narcissistic choice of the object prevails. Whereas in normal processes, when one ceases to love something or someone, there is a withdrawal of the libido from such object, as well as a consequent shifting to a new object; here there is a degradation of the ego. The free libido does not turn itself to the external object, but to the very ego. There occurs an identification of the ego with the abandoned object.

In order to understand this process, Freud bids us to reconstruct it: he takes into consideration that, if on one hand there was a strong fixation of the object of love, on the other hand - and contradictorily - there was little investment in the object, which presupposes that his choice has been made upon narcissistic bases. "The narcissistic identification with the object then becomes a substitution for the love investment, implying that, regardless of the conflict, the loverelationship with the loved one does not have to be left." Then he claims that "Such substitution of the object of love through identification is an important mechanism for narcissistic affections" (op. cit., p. 63). Thus there is a regression to the original narcissism, which will meet with a net of meanings coming from unconscious objectal investments that will be ready to stand for this image identified in the ego.

But what actually counts in melancholia is the conflict of ambivalence; if, on one hand, there is a strong libidinal investment in the object lost by the ego, there is a huge hatred against the damage provoked by its abandoning. Thus, hatred and rage lean against terms of love and some of the ego is identified with the object that used to be so dear, but - due to the pain provoked by its loss - it starts a violent fight: "hatred and love fight each other: one to disconnect the libido from the object; the other for the defense of this position of libido from all sorts of attack" (op. cit., p. 81).

In this text we shall find the basis to discuss what we suppose to be a mechanism present in cases of eating disorders, particularly in nervous anorexia. Not infrequently these patients - most of them women - associate the beginning of anorexia with an important loss: a love disappointment, a change, a financial loss, the loss of a place or status etc. The work of mourning must be started, and what we see is what gets closer to - or even beyond - a melancholic process: this patient invariably believes that there is something to be changed in her to prevent a new loss. Her body must be changed, since she believes that "had she not been fat and full of deformations", nothing of the kind would have happened. Here we do not find just a self-indictment or a self-reproach. Something has to be done in her body to change the state of things.

The amazing thing is that in most cases we are not before someone who could be called fat or deformed at the moment of such decision. A patient with 
anorexia has rarely started a diet prescribed by a specialized professional. What body representation is this? What is the image/object this patient identifies herself with?

In a previous work (GONZAGA, 2010), we proposed a digression allowing us to understand how this body imagined by the patient with anorexia should explain the narcissistic construction of its identity. In this respect, the identifying processes would be result of a narcissistic motherly super-investment that would turn such patients into hostages of the images projected by this process, provoking so much unfamiliarity when they become ill. A body they cannot recognize as their own, a body that provokes neither admiration nor pleasure. We then tried to understand such problem as the destination of narcissism in which - since it cannot overcome what would be the ideal of the other imposed upon its psychism - it recedes to the body identified with what has been incorporated. A pulsional dualism provoking estrangement and pain: a libido that should be disconnected from an object and gain new investments goes back to the corporal ego embodying very primitive identifying representations. In that article we concluded that, in order to go on living, the patient with anorexia has to disembody this intrusive object embedded in what we consider her bodily narcissism

In On Narcissism: an Introduction (1914), Freud claims that the objectal choice made by women is preferably narcissistic: they see as a sex object those who love them or turn them into their ideal, thus giving them back their selfesteem. Hugo Bleichmar (1989) deals with narcissism taking into consideration two sorts of problem: the relationship between ego and object, and the living of perfection, self-satisfaction, and fullness. Considering primary narcissism an object, since the body itself or the "self" could be the object of love for the subject, Bleichmar emphasizes the importance of the other in the construction of representations that will be the basis for identifications. He also claims that 'identification and narcissism are incomprehensible if they are not articulated to a division between conscious and unconscious, which is essential for psychoanalysis. The ego and the other are the same in terms of the unconscious image" (p.36). Bleichmar also claims that the love of narcissism is characterized by idealization, which potentizes feelings of perfection, beauty, delight and intelligence, among other qualities associated to ideals.

He then claims that such valorizations imply a symbolical order exterior to the subject, and where he is inscribed. "It is the other that turns simple anatomic objects into something worth being admired as beautiful. It is then easy to figure out the multiple situations in which a mother can turn into something adored the eyes and locks of her daughter or into intellectual or physical productions of them" (op. cit. p. 38). And it also marks that parental narcissism will be directly

Rev. Latinoam. Psicopat. Fund., São Paulo, v. 15, n. 3, p. 649-656, setembro 2012 (Suppl.) 
embedded in the satisfaction of their own needs of hyper-esteem when valorizing their children.

What would then happen to our patients who develop anorexia?

When we consider the largest incidence of this pathology in teenager girls, we inevitable turn to mournings which are peculiar to this stage in their development - mourning concerning their own body, childish identity, parents in childhood, and bisexuality. What seems to be a difficult task is usually maximized by other meaningful losses we already mentioned, such as changes, separations, travels, interchange etc.), and so we see this young girl to ascribe the cause of her failure to something in her body.

Above all, it seems that what could be a work of melancholia capable to offer her the chance to find the narcissistic representation typical of this process in mental representations goes much further, transferring to the body the sadism already characterized by Freud as inherent to this complex. The ambivalence of love relationships, which already configures in melancholia the love and the hatred towards the object, here finds a peculiar expression. When reaching adolescence, the girl faces the task of turning off the representations belonging to her childish word, and it seems to us that the force of investments prevents this turning off from following a normal mourning process. Freud emphasizes that, in order to achieve a work of mourning, representations should find a stream, flowing from the unconscious system to the pre-conscious/conscious, something that does not happen in melancholia: "this stream is clogged for the work of melancholia, perhaps as a consequence of innumerable causes or the action of a group causes" (op. cit., p. 81).

More than a clogging preventing the derivation of unconscious mental representations, what we can observe is that such derivation goes towards bodily representations. That is why we propose to see as a failure the work of melancholia, inasmuch as hatred and sadism are directed to the very body receiving such identifications. In this case, it seems to us that in this regressive work the ego already finds the very object incarnated - and not the "shadow of the object", which Freud claims to be a central characteristic of the work of melancholia.

Going back to the Freudian text, when it deals with the tendency to suicide in melancholia, we shall have to take into consideration that “... the analysis of melancholia shows us that the ego can only kill itself - through the return of the investment in the objet - if it can be treated as an object (my italics), if it can attract to itself the hostility that is valid for the object, thus representing the primeval reaction of the ego against objects from the external world" (op. cit., p. 59). The confusion in the mirror of the girl with anorexia seems to tell us about the lack of discernance between ego, object and bodily ego. This confusion is

Rev. Latinoam. Psicopat. Fund., São Paulo, v. 15, n. 3, p. 649-656, setembro 2012 (Suppl.) 
provoked by the super-investment of the motherly narcissism, which prevents the girl to achieve a successful melancholic process - capable to offer her mental representations for the elaboration of her mourning, thus offering the ego its main attribution: discernance. She fails, she cannot realize she is punishing her body; she is fully convinced that if she does not take any food she will be taking care a body deformed by fat. In other words, she is trying to disinvest in the libido falling upon the object of love and hatred. She reacts in a mechanic way: she fights hard, with an energy coming from the withdrawal of the objectal libido she fights against herself, although she believes she has overcome the enemy.

Death does not come into consideration as a real possibility for a patient with anorexia; she does not intend to die, but she will be able to live only if she can kill her specular image.

\section{Bibliography}

Bleichmar, H. Depressão: um estudo psicanalítico. 3. ed. Porto Alegre: Artes Médicas, 1989.

Freud, S. (1915). Sobre o narcisismo: uma introdução. In: Edição Standard Brasileira das Obras Psicológicas Completas de Sigmund Freud. Rio de Janeiro: Imago, 1976. v. XIV.

Freud, S. Luto e melancolia. São Paulo: Cosac Naify, 2011.

Gonzaga, A.P. "Se esse corpo fosse meu...”. Considerações sobre o estranhamento na anorexia. In: Gonzaga, A.P; Weinberg, C. (org.). Psicanálise de transtornos alimentares. São Paulo: Primavera Editorial, 2010.

\section{Abstract}

(Anorexia: um fracasso do trabalho da melancolia)

As autoacusações dirigidas ao corpo por pacientes com transtornos alimentares nos levaram a questionar um fracasso no trabalho da melancolia. Proposto por Freud em 1915, esse processo teria por objetivo reparar uma perda sentida como insuportável pelo ego e que dispara uma batalha violenta pela ambivalência de sentimentos dirigida ao objeto perdido. $O$ ódio derivado é dirigido à sombra do objeto que recai sobre o ego. Especialmente na anorexia nervosa, nos parece que há um movimento regressivo que vai além.

Palavras-chave: Transtornos alimentares; adolescência; melancolia, narcisismo 
(Anorexie: l'échec du travail de la mélancolie)

Les auto-reproches que les patients souffrant de troubles alimentaires formulent contre leur propre corps nous ont conduites à nous interroger sur l'échec du travail de la mélancolie. Proposé par Freud en 1915, ce processus aurait pour but de réparer une perte ressentie par l'ego comme insupportable et qui déclenche une bataille féroce en raison de l'ambivalence des sentiments par rapport à l'objet perdu. La haine qui en résulte est dirigée vers l'ombre de l'objet et retombe sur le moi. Particulièrement dans le cas de l'anorexie mentale, nous avons l'impression qu'il ya un mouvement régressif qui va au-delà.

Mots clés: Troubles alimentaires; adolescence; mélancolie, narcissisme

(Anorexia: un fracaso en el trabajo de la melancolía )

Las auto-acusaciones dirigidas al cuerpo en los pacientes con trastornos de la conducta alimentaria nos ha llevado a cuestionar un fracaso en el trabajo de la melancolía. Propuesto por Freud en 1915, este proceso tendría como objetivo reparar una pérdida sentida por el ego como insoportable, y que desencadena una feroz batalla por la ambivalencia de los sentimientos dirigidos al objeto perdido. El odio derivado es dirigido a la sombra del objeto que recae sobre el ego. Especialmente en anorexia nerviosa, parecería que hay un movimiento regresivo que va más allá.

Palabras clave: Trastorno de las conductas alimentarias, adolescencia, melancolia, narcisismo

(Anorexie: Ein Versagen der Melancholieverarbeitung)

Die Selbstbeschuldigungen, die Patienten mit Essstörungen an den Körper senden, haben uns dazu geführt, ein Versagen der Melancholieverarbeitung zu erwägen. Nach Auffassung von Freud (1915), sei das Ziel dieses Prozesses die Heilung eines Verlustes, der vom Ego als unerträglich empfunden wird und wegen der zwiespältigen Gefühle gegenüber dem verlorenen Gegenstand einen brutalen Kampf auslöst. Der daraus erfolgende Hass wendet sich gegen den Schatten des Gegenstandes und fällt zurück auf das Ego. Insbesondere bei der 'Anorexia nervosa' findet unserer Ansicht nach eine regressive Bewegung statt, die weiter geht.

Schlüsselwörter: Essstörungen, Pubertät, Melancholie, Narzissmus

Citation/Citação: Gonzaga. A.P. Anorexia: A Failure of the Work of Melancholia. Revista Latinoamericana de Psicopatologia Fundamental, São Paulo, v. 15, n. 3, p. 649-656, sept.2012 (Suppl.).

Editor/Editor do artigo: Prof. Dr. Manoel Tosta Berlinck

Rev. Latinoam. Psicopat. Fund., São Paulo, v. 15, n. 3, p. 649-656, setembro 2012 (Suppl.) 
Received/Recebido: 30.5.2012 / 5.30.2012 Accepted/Aceito: 25.7.2012 / 7.25.2012

Copyright: (C) 2009 University Association for Research in Fundamental Psychopathology / Associação Universitária de Pesquisa em Psicopatologia Fundamental. This is an open-access article, which permits unrestricted use, distribution, and reproduction in any medium, provided the original author and source are credited. / Este é um artigo de livre acesso, que permite uso irrestrito, distribuição e reprodução em qualquer meio, desde que o autor e a fonte sejam citados.

Funding/Financiamento: The authors have no support or funding to report. / Os autores declaram não ter sido financiados ou apoiados.

Conflict of interest/Conflito de interesses: The authors declare that has no conflict of interest. / Os autores declaram que não há conflito de interesses.

\section{Ana Paula Gonzaga}

Psychoanalyst, Coordinator of the Psychology Team of the Program of Assistance, Teaching and Research of Eating Disorders in Childhood and Adolescence, Service of Child Psychiatry of Hospital das Clínicas, Medicine College, University of São Paulo - PROTAD-SEPIAIPq-FMUSP (São Paulo, SP, Br.); Coordinator of Clinic of Studies and Researches in Psychoanalysis of Anorexia and Bulimia - CEPPAN (São Paulo, SP, Br.); Coordinator of the Psychology Team of Casa Viva, Clinic for the Treatment of Eating Disorders (São Paulo, SP, $\mathrm{Br}$.).

Rua dr. Guilherme Bannitz, 90/93 - Itaim Bibi

04532-060 São Paulo, SP, Brasil

Fone: (11) 3045-1883

e-mail: anapaulagonzaga@uol.com.br

Rev. Latinoam. Psicopat. Fund., São Paulo, v. 15, n. 3, p. 649-656, setembro 2012 (Suppl.) 